\title{
LIGHT-EVOKED SUSTAINED INHIBITION IN MUDPUPPY RETINAL GANGLION CELLS
}

\author{
JaCk H. Belgum, David R. DvoraK and John S. McReynolds \\ Department of Physiology, The University of Michigan, Ann Arbor, MI 48109, U.S.A.
}

(Received 22 December 1980; in revised form 26 May 1981)

\begin{abstract}
Intracellular recordings were made from off-center ganglion cells in the retina of the mudpuppy, Necturus maculosus. Current-voltage measurements revealed that the sustained light-evoked hyperpolarization of thesc cclls is duc to a sustained inhibitory synaptic input with a reversal potential more negative than the resting potential.
\end{abstract}

\section{INTRODUCTION}

Many investigators have concluded that the sustained responses and basic receptive field properties of offcenter retinal ganglion cells are determined by modulation of an excitatory synaptic input from hyperpolarizing bipolar cells (Miller and Dacheux, 1976; Naka, 1976, 1977; Baylor and Fettiplace, 1977; Wunk and Werblin, 1979). It has been inferred that the excitatory synapse is tonically active in darkness, when the hyperpolarizing bipolar cells are depolarized, and that the activity of the synapse is reduced during center stimulation, when these bipolar cells are hyperpolarized. Off-center ganglion cells also receive an inhibitory input (presumably from transient amacrine cells) which is active for a brief period following a change in illumination (Wunk and Werblin, 1979).

In the present paper we report that off-center ganglion cells in the mudpuppy retina receive a third type of synaptic input which is inhibitory and whose activity is sustained during prolonged center stimulation. Our study indicates that the sustained responses of these ganglion cells are due to changes in sustained excitatory and inhibitory synaptic inputs.

\section{METHODS}

Intracellular responses were recorded from offcenter ganglion cells in superfused mudpuppy eyecups using micropipettes filled with $4 \mathrm{M}$ potassium acetate. Electrode resistance, measured in the bathing solution, ranged from 400-800 M $\Omega$. A high input impedance preamplifier with capacity compensation (Colburn and Schwartz, 1972) was used to record membrane potential and to inject constant current through the recording electrode. An active bridge circuit was used to balance out the voltage drop across the electrode resistance during current injection. For the electrodes used in this study, voltage was proportional to current over the range of about $\pm 0.05 \mathrm{nA}$; nonlinear properties were evident with greater currents and were corrected for by measuring the current-voltage propertics of the electrode before and after cach recording.

The stimulus was a spot of white light $(70-200 \mu \mathrm{m}$ dia) centered in the cell's receptive field. The size of the stimulus was small relative to the size of the receptive field center, which is $500-750 \mu \mathrm{m}$ in diameter (Karwoski and Burkhardt, 1976). Stimuli were typically $2-5 \mathrm{sec}$ duration and were presented every $20 \mathrm{sec}$. The unattenuated light stimulus at the retina was the photopic equivalent of $3.25 \times 10^{15}$ photons $\cdot \mathrm{cm}^{-2} \cdot \mathrm{sec}^{-1}$ at $575 \mathrm{~nm}$, the $\lambda_{\max }$ of mudpuppy cones (Liebman, 1972). Surround antagonism could be evoked with appropriate stimuli but will not be discussed in this report.

\section{RESIIITS}

The response of an off-center gangion cell to illumination of its receptive field center is a sustained hyperpolarization which persists for the duration of the light stimulus (Fig. 1a). At light on, the hyperpolarization is rapid and transiently excecds the maintained level. At light off, the cell depolarizes beyond the previous dark level and generates a burst of action potentials. The changes in resistance which occur during the light response are illustrated in Fig. 1b. Resistance was measured by injecting hyperpolarizing constant current pulses $(-0.1 \mathrm{nA})$ through the recording electrode. The amplitude of the resulting voltage displacement is proportional to the input resistance of the cell at that time. In darkness the input resistance of this cell was $280 \mathrm{M} \Omega$. Throughout the entire hyperpolarizing light response the resistance was only $100 \mathrm{M} \Omega$, which corresponds to a conductance increase of $6.4 \mathrm{nS}$. Note that conductance was also elevated. relative to darkness, during the offdepolarization. Similar measurements were made in 31 cells and in every case the sustained hyperpolariz. ation was associated with a maintained increase in conductance, even with light stimuli as long as $30 \mathrm{sec}$ in duration. 


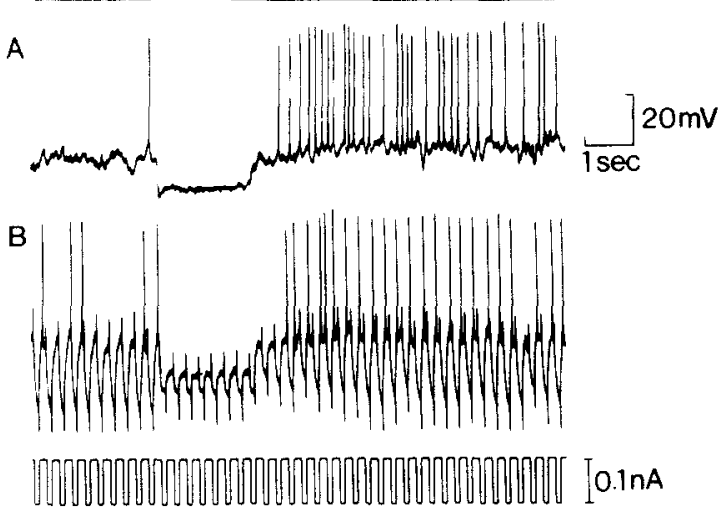

Fig. 1. Time-course of light-evoked resistance changes in an off-center ganglion cell. (A) Response to a $70 \mu \mathrm{m}$ dia spot centered in the receptive field. intensity $-2.4 \mathrm{log}$ units. (B) Response to identical light stimulus as above with superimposed $-0.1 \mathrm{nA}$ constant current pulses. Current intensity shown in the lower trace. Voltage displacement caused by each pulse is proportional to the input resistance of the cell at that time.

The effect of steady hyperpolarizing current on the response of another off-center ganglion cell is shown in Fig. 2a. Constant current steps, $10 \mathrm{sec}$ in duration, were applied through the recording electrode. and the light stimulus was presented $2 \mathrm{sec}$ after the onset of each step. The normal response (zero current) is shown in the upper trace: membrane potential in darkness was $-54 \mathrm{mV}$. and all potentials are indicated relative to this value. Notice that as the cell is polarized to more negative potentials, the sustained hyperpolarization decreases in amplitude and eventually reverses polarity. as is clearly seen in the

A

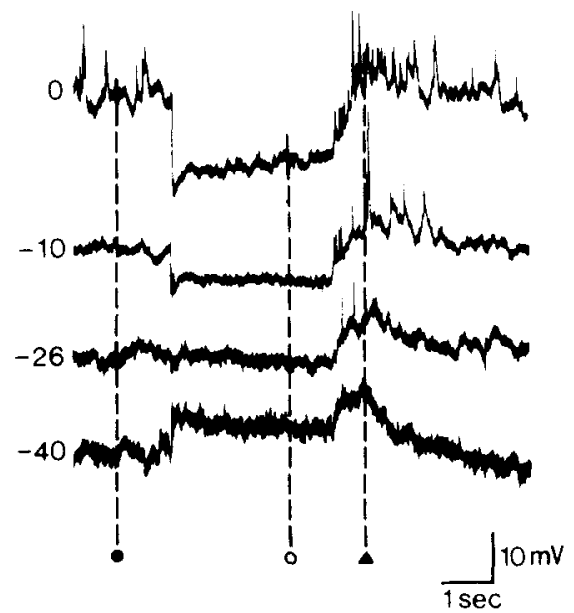

bottom trace. The transient phase of the hyperpolarizing response behaves similarly, while the off-depolarization steadily increases in amplitude. The current voltage (I-V) relations of this cell are shown in Fig. 2b. In this example, depolarization by more than $15 \mathrm{mV}$ relative to the dark potential causes a large decrease in resistance. At less positive potentials, where this voltage-dependent process is inactive. the data points fall on straight lines. The I- $\mathrm{V}$ relation measured in steady darkness (filled circles) has a slope resistance of $250 \mathrm{M} \Omega$. Center stimulation causes a maintained hyperpolarization of $13 \mathrm{mV}$, and the $\mathrm{IVV}$ relation for this part of the light response copen circles) has a slope resistance of $130 \mathrm{M} \Omega$ : thus light caused a conductance increase of $3.7 \mathrm{nS}$ relative to steady darkness. The reversal potential for the sustained hyperpolarizing response is $28 \mathrm{mV}$ more negative than the normal dark potential. The I- $\mathrm{V}$ relation for the off-depolarization (triangles) has a slope resistance of $200 \mathrm{M} \Omega$. The extrapolated potential at which the depolarizing off-response reverses polarity is more positive than the dark potential, but actual reversal cannot be demonstrated because of the voltagedependent conductance increase.

\section{DISCUSSION}

These results show that the light-evoked sustained hyperpolarization of mudpuppy off-center ganglion cells is due to the action of an inhibitory synaptic input which increases conductance and which has a reversal potential more negative than the membrane potential in darkness. Further, the study provides evidence that the excitatory synaptic input to these cells

B

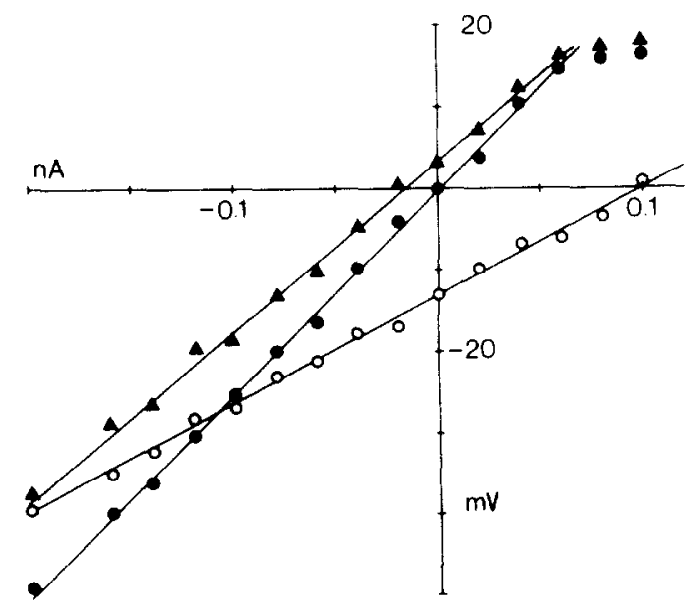

Fig. 2. Current-voltage relations of an off-center ganglion cell. (A) Responses to identical light stimuli (200 $\mu \mathrm{m}$ dia spot. intensity $-7.2 \mathrm{log}$ units) at four different membrane potentials. Numbers at left of each trace indicate membrane potential relative to resting dark potential. Onset of each polarizing current step was $1.5 \mathrm{sec}$ before beginning of records. (B) $\mathrm{I}-\mathrm{V}$ relations for this cell measured at times indicated in (A) in darkness (filled circles). during the light-evoked sustained hyperpolarization (open circles), and during the off-depolarization (triangles). Resting potential in darkness was $-54 \mathrm{mV}$. 
also increases conductance and has a reversal potential more positive than the dark potential. Since the conductance during the sustained hyperpolarization was always greater than the conductance in darkness it was not possible to assess the changes in excitation which may occur during this part of the response. We assume, however, that there is a light-evoked reduction in excitation and that the resulting conductance decrease is obscured by the larger conductance increase due to the inhibitory input. Thus, it appears that the response may involve changes in excitation and inhibition. which implies that the value of the reversal potential shown in Fig. 2 is the net reversal potential for the hyperpolarizing response and not necessarily that of the inhibitory input itself.

There are a number of reasons to suggest that the light-evoked sustained inhibition is a separate synaptic input rather than simply a maintained component of the transient inhibitory input previously described. First, outward currents associated with transient inhibitory inputs in mudpuppy retinal ganglion cells decay completely within 400-600 msec (Werblin, 1977). Similar transient inhibitory inputs have been described for all classes of tiger salamander ganglion cells and have time-courses of less than $1 \mathrm{sec}$ (Wunk and Werblin, 1979). Finally, we have shown that the transient component of the hyperpolarizing response can be pharmacologically blocked, leaving the sustained component of the response and its associated conductance increase intact (Dvorak et al., 1980).

The presynaptic source of the tonic inhibitory input should be center-depolarizing cells, which include depolarizing bipolar cells and sustained depolarizing amacrine cells. Anatomical investigations and transmitter localization studies tend to favor the amacrine cells (e.g. Famiglietti et al., 1977; Nelson et al., 1978; Bruun and Ehinger, 1974; Voaden, 1976; Marc et al., 1978; Pourcho, 1980), but recent work on cat retina suggests a possible inhibitory role for certain bipolar cells (McGuire et al., 1980).

Dacheux et al. (1979) concluded that the lightevoked sustained hyperpolarization of mudpuppy offcenter ganglion cells was due entirely to disfacilitation, that is, a reduction in excitation. That conclusion stems from the observation that resistance during illumination was higher than in darkness. In their study, resistance was measured by injecting $0.1 \mathrm{nA}$ depolarizing current pulses through the recording clcctrode. Since off-center ganglion cells can exhibit a pronounced voltage-dependent conductance increase when they are depolarized beyond the dark potential (see Fig. 2 and also Wunk and Werblin, 1979, for similar data from tiger salamander). To illustrate how this nonlinear property of the membrane can contaminate measurements of synaptically-mediated resistance changes, we have included $I-V$ relations for another cell (Fig. 3) in which strong rectification occurs when the membrane is depolarized as little as $5 \mathrm{mV}$ relative to the dark potential. For this cell, voltage displacements produced by depolarizing currents

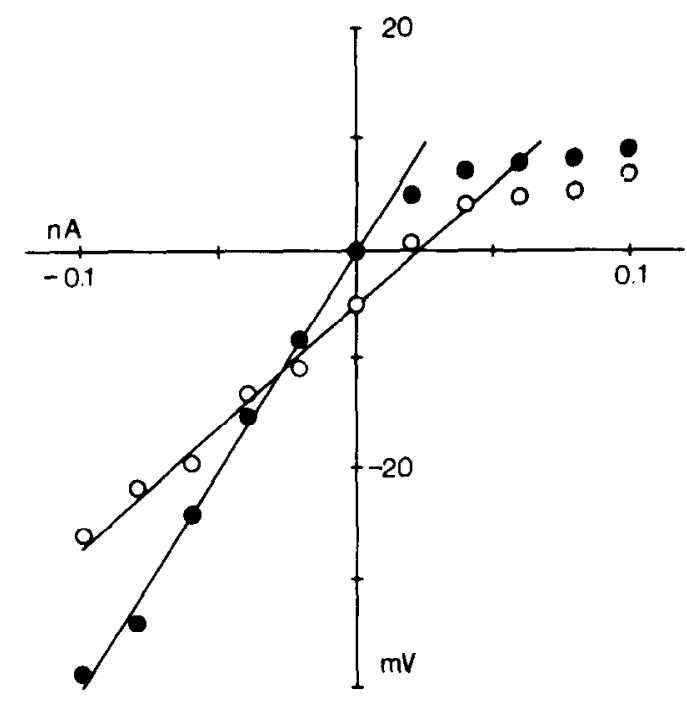

Fig. 3. Current-voltage relations of an off-center ganglion cell measured in darkness (filled circles), and during illumination of the receptive field center (open circles), as in Fig. 2. Stimulus was a $200 \mu \mathrm{m}$ dia spot, intensity $-4.6 \mathrm{log}$ units. Resting potential in darkness was $-59 \mathrm{mV}$.

pulses would indicate a higher resistance in light than in darkness, even though measurements made with hyperpolarizing currents (i.e. over the linear range of the I-V relations) clearly show that resistance is much lower in light than in darkness.

\section{REFERENCES}

Baylor D. A. and Fettiplace R. (1977) Transmission from photoreceptors to ganglion cells in turtle retina. J. Physiol. 271, 391-424.

Bruun A. and Ehinger B. (1974) Uptake of certain possible neurotransmitters into retinal neurons of some mammals. Expl Eye Res. 19, 435-447.

Colburn T. R. and Schwartz E. A. (1972) Linear voltage control of current passed through a micropipettc with variable resistance. Med. Biol. Eng. 10, 504-509.

Dacheux R. F., Frumkes T. E. and Miller R. F. (1979) Pathways and polarities of synaptic interactions in the inner retina of the mudpuppy: I. Synaptic blocking studies. Brain Res. 161, 1-12.

Dvorak D. R., Belgum J. H. and McReynolds J. S. (1980) Glycine mediates transient IPSPs and GABA mediates sustained IPSPs in mudpuppy retinal ganglion cells. Soc. Neurosc. Abstr. 6, 212.

Famiglietti E. V. Jr, Kaneko A. and Tachibana M. (1977) Neuronal architecture of on and off pathways in carp retina. Science 198, 1267-1269.

Liebman P. A. (1972) Microspectrophotometry (MSP) of photoreceptors. In Handbook of Sensory Physiology (Edited by Dartnall H. J. A.), Vol. VII/I, pp. 481-528. Springer-Verlag, Berlin. pp. 481-528.

McGuire B. A., Stevens J. K. and Sterling P. (1980) Beta ganglion cells receive convergent input from 2 types of cone bipolars. Soc. Neurosci. Abstr. 6, 347.

Marc R. E., Stell W. K., Bok D. and Lam D. M. K. (1978) GABA-ergic pathways in the goldfish retina. $J$. comp. Neurol. 182, 221-245.

Miller R. F. and Dacheux R. F. (1976) Synaptic organization and ionic basis of on and off channels in mudpuppy retina. III. A model of ganglion cell receptive field organization based on chloride-free experiments. J. gen. Physiol. 67, 679-690. 
Naka K. I. (1976) Neuronal circuitry in the catfish retina. Incest. Ophthal Visual Sci. 15. 226235.

Naka K. 1. (1977) Functional organization of catfish retina. I. Vurophisiol 40, 2643.

Nelson R.. Famiglietti E. V. Jr and Kolb H. (1978) Intratcellulat staining reveals different levels of stratification for on- and off-center gangion cells in cat retina. $J$. Nettrophistol. 41, 472483.

Pourcho R. 11980 Uptake of $\left[{ }^{3} \mathrm{H}\right]$-glycine and $\left[{ }^{x} \mathrm{H}\right]$-GABA by amacrine cells in the cat retinat. Brain $R_{t}, 198,333,340$
Voaden M. J. (1976) Gamma-aminobutyric acid and glycine as retinal neurotransmitters. In Transmitters in the Visual Process (Edited by Bonting S. L.I. pp. 107126. Pergamon Press, Oxford.

Werblin F. S. (1977) Regenerative amacrine cell depolarization and formation of on-off ganglion cell responsc. $J$, Phisiol. 264, 767.785.

Wunk D. F. and Werblin F. S. (1979) Synaptic inputs to the ganglion cells in the tiger salamander retina. $J$. gen. Phisiol. 73, 265286 